\title{
Al-Khawarizmi : Algebra Factory Method
}

\author{
Agus Hikmat Syaf, Riva Lesta Ariany, Tika Kalina Rachmawati \\ Program Studi Pendidikan Matematika \\ UIN Sunan Gunung Djati Bandung \\ Bandung, Indonesia \\ tikakarlinarachmawati@uinsgd.ac.id
}

\begin{abstract}
Many students find it difficult to understand the concept of algebra because it is abstract, so it is necessary that the abstract method of algebra become more concrete, one of the methods that can be used is Al-Khawarizmi method. This Research is intended to analyze students' mistakes in working out factoring using Al-Khawarizmi, so that the mistakes can be minimized in the future. This research is a qualitative research with sampling through purposive sampling technique. The study was held in SMP (Junior High School) Negeri 2 Cileunyi. The subjects were 32 students of class IX. The main data was from the results of the factoring test by Al-Khawarizmi. Data analysis was carried out through reduction, presentation data, and withdrawal. This study describes the student's mistakes in working out the factoring using Al-Khawarizmi method which includes counting error, visualization of equation, algorithm, measurement of answers, and student's accuracy. From the result of research done by student in mathematical operation equal to $15.38 \%$, percentage of error in visualization equation $21.54 \%$, error in algorithm $4.62 \%$, student error in answer is $29.23 \%$, and student error in accuracy is $29.23 \%$. This indicates that the error in the level of language is significant. As a whole this method is effective to use.
\end{abstract}

Keywords-Al-Khawarizmi; algebra; error analysis; factoring

\section{INTRODUCTION}

Algebra is still one of the most abstract mathematical parts considered by students. This perception is indirectly a supporting evidence for why many students have difficulty understanding algebra, both in concept and in application. Based on the previous research, it is known that the cause of student error in solving the problem of algebraic form factorization can be seen from various things, among others, because students are not careful in reading, not careful in thinking, weakness in problem analysis, less persistent, less able to see the usual problems in the way / new or unusual approaches, and low self-confidence [1].

According to Knuth, Stephens, McNeil, and Alibali [2] some misconceptions in algebra are, among others, in understanding the same signals that are essential in solving algebraic problems. In the concept of algebra, students also have difficulty in the process of transition from arithmetic to algebraic thinking, possibly because students consider the same mark to be an indicator of the results of operations performed or answers to the problem posed. This type of error distorts the perception of the equations and the intermediate objectives necessary for the solution. Another form of problem that seems important in solving initial algebraic equations is a negative sign, working with negative numbers is inherently difficult for students. The student fails to understand the modified problem or does not understand how to change or move the negative sign affecting the equation. In addition, students also experience constraints in the process of transition from arithmetic to algebraic thinking.

Algebra, which essentially attempts to parse a problem with symbolization to make it easier to solve, is still not effectively used, because the students' mind structure is often more difficult to understand the problem in algebraic form due to its abstraction. The term algebra usually denotes various kinds of mathematical ideas and techniques, more or less directly associated with formal manipulation of abstract symbols and/or with finding the solutions of an equation [3]. Algebra has existed since the days of ancient Babylon, the Babylonians developed a form of algebra that is quite fascinating at its time, on its development the rules of algebra procedure are proclaimed as if they were divine revelations, which the reader must accept and follow as truly believers.

Arabic mathematicians are much influenced by Greek especially inspired by the Euclid Elements. They seem to believe that a geometrical argument should be convincing, so algebra is presented as a geometric demonstration [4]. The most famous Arabic mathematician is Muhammad Ibn Musa $\mathrm{Al}$ Khawarizmi who lived during the reign of $\mathrm{Al}$ Ma'mun. Algebra and algorithms appeared in the IX century. Having polynomial equality expertise, Muslim mathematician AlKhawarizmi wrote his famous book al-jabr wa'l muqabala in Baghdad [5]. He is known as the father of algebra, because of his brilliant thoughts about algebra. It also uses rhetoric algebra, which means all equations are written in sentence form. Translations into algebraic forms, where only the symbols are used, can be seen in other mathematician workmanship named Ibn al-Bunna 'al Marakushi. AlKhwarizmi introduced the value of the decimal place and made it widespread in Arabia and later in Europe [6]. AlKhwarizmi's work embodies much of what is central to Islamic contributions in this field. He declared his book to be intended as one of practical value, yet this definition hardly applies to what one finds there. In the first part of his book Al-Khwarizmi presented the procedures for solving six types of equations: squares equal roots, squares equal numbers, roots equal numbers, squares and roots equal numbers, squares and numbers equal roots, and roots and numbers equal a square[3].

With regard to quadratic equations, Al-Khawarizmi divides them into three fundamental types [4]. 
$x^{2}+a x=b$

$x^{2}+b=a x$

$x^{2}=a x+b$

$$
x^{2}+2 x-15=0
$$

At that time, the general form of algebra expressed by $\mathrm{Al}$ Khwarizmi was that only positive coefficients were accepted. Al-Khawarizmi then demonstrates a quadratic equation in the form of geometry. The example of query equation that is proposed include a number when squared plus ten times the number is equal to 39. Algebraic work is geometrically first by making a square $\mathrm{ABCD}$ that has a side length of $\mathrm{x}$, then add $10 \mathrm{x}$ by dividing it into 4 rectangles to form a larger square.

$$
x^{2}+10 x=x^{2}+4\left(\frac{10}{4} x\right)
$$

Then add four small boxes that each have the same width, it can be seen in figure 1 . So that we can have a large square area equal to 64 . Therefore, a large square side is equal to 8 (5), so note that the square side of $\mathrm{ABCD}$ is 3 (6).

$\left(x+\frac{10}{2}\right)^{2}=\left(x^{2}+10 x\right)+4\left(\frac{10}{2}\right)^{2}=39+\frac{10}{2}=39+25=64$

$x+\frac{10}{2}=8$

$x=3$

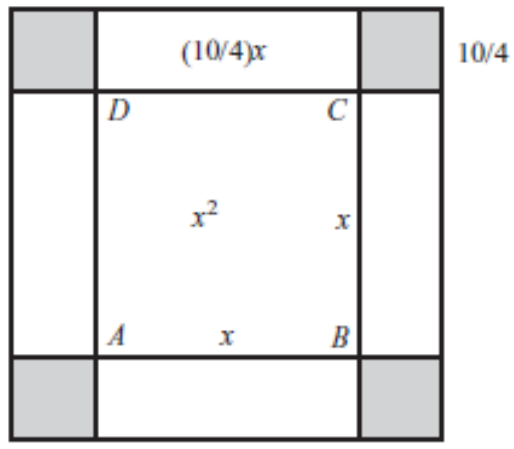

Fig. 1. Algebra demonstrating.

When considered carefully, what $\mathrm{Al}$ - Khawarizmi put forth can also be used to solve the factorization of quadratic equations. It is also possible to make the quadratic equation concrete through a demonstration of geometry. For example to find the factor of equation see figure 2 .$$
x^{2}+2 x=15
$$

Luas Persegi Besar $=$ Luas $A+4$. Luas $B+4$. Luas $C$

$(x+1)^{2}=(x \cdot x)+4\left(\frac{2}{4} x\right)+4\left(\frac{2}{4} \cdot \frac{2}{4}\right)$

$(x+1)^{2}=x^{2}+2 x+1$

$(x+1)^{2}=15+1$

$(x+1)^{2}=16$

$(x+\stackrel{1}{1})= \pm \sqrt{16}$

$(x+1)= \pm 4$

Sehingga, $(x+1)=4$, maka faktornya $(x-3)$

$(x+1)=-4$, maka faktornya $(x+5)$

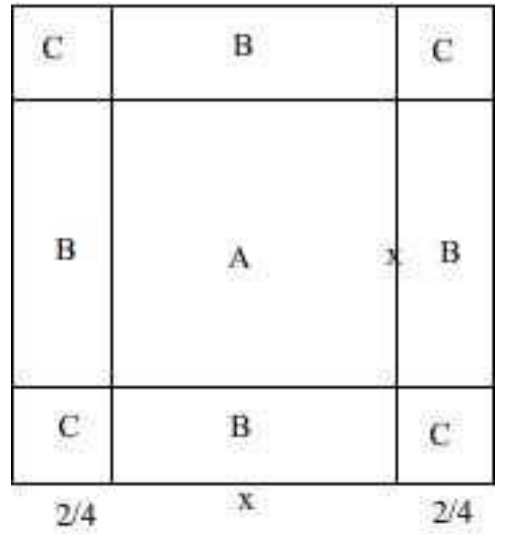

Fig. 2. Visualization of quadratic equations with geometry. 
Another example of using this method, in the solution of the equation. In the same way we get (20) it can be visualized in Figure 3. And obtained factor (33) using Al-Khawarizmi method.

$$
4 x^{2}+6 x-4=0 \text { atau } 4 x^{2}+6 x=4
$$

Luas Persegi Besar $=4$. Luas $A+8$. Luas $B+4$.Luas $C$

Sisi persegi besar $=\frac{6}{8} x+x+x+\frac{6}{8} x=2 x+\frac{12}{8}=2 x+\frac{3}{2}$

Luas Persegi Besar $=\left(2 x+\frac{3}{2}\right)^{2}$

Luas Persegi Besar $=\left(2 x+\frac{3}{2}\right)^{2}=4 \cdot x \cdot x+8 \cdot\left(\frac{6}{8} x\right)+4 \cdot\left(\frac{6}{8}\right)^{2}$

$\left(2 x+\frac{3}{2}\right)^{2}=4 x^{2}+6 x+4 \cdot\left(\frac{6}{8}\right)^{2}$

$\left(2 x+\frac{3}{2}\right)^{2}=\left(4 x^{2}+6 x\right)+4 \frac{36}{64}$

$\left(2 x+\frac{3}{2}\right)^{2}=\left(4 x^{2}+6 x\right)+\frac{18}{8}$

$\left(2 x+\frac{3}{2}\right)^{2}=4+\frac{18}{8}$

$\left(2 x+\frac{3}{2}\right)^{2}=\frac{32+18}{8}$

$\left(2 x+\frac{3}{2}\right)^{2}=\frac{25}{4}$

$$
\left(2 x+\frac{3}{2}\right)= \pm \sqrt{\frac{25}{4}}
$$

$\left(2 x+\frac{3}{2}\right)=-\frac{5}{2} \operatorname{atau}\left(2 x+\frac{3}{2}\right)=\frac{5}{2}$

$(2 x+4) \operatorname{atau}(2 x-1)$

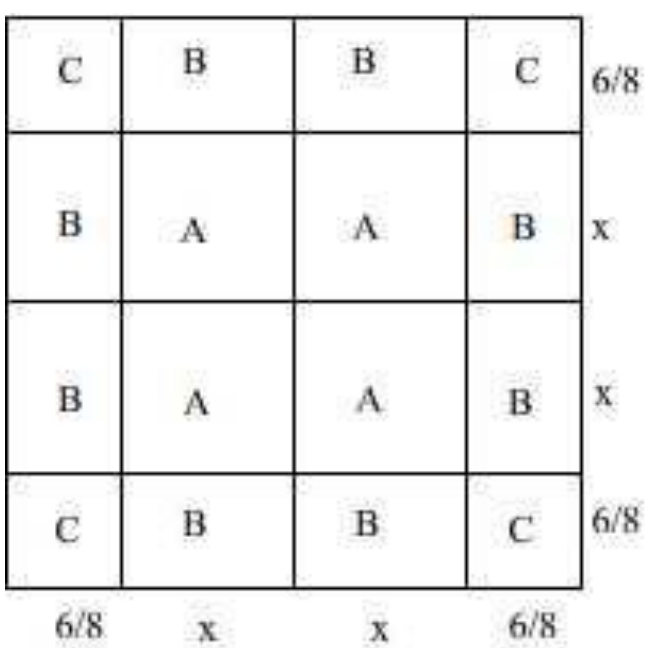

Fig. 3. Algebra visualization

This research is a qualitative research. The subjects of the study were 32 ninth grade students of SMP Negeri 2 Cileunyi Academic Year 2017/2018. The sample was chosen by using purposive sampling technique. The data collection was carried out through test. The test was an essay test about algebraic factoring. The instrument used in this research is a test of factoring by Al Khawarizmi. First, students are taught how to do factoring by Al Khawarizmi method, then after the students understand, then the students are given tests. The results of student work are then analyzed about counting operation errors, visualization of equations, algorithms, summing up answers, and student accuracy. The purpose of this study was to analyze students' errors in solving algebraic factorization problems using Al-Khawarizmi method. Furthermore, the purpose of this study is to see how far the probability of introducing this method to junior high school students is effective in solving algebraic factorization problems.

\section{RESULTS AND DISCUSSION}

Analysis of students' work on algebraic factorization using Al-Khawarizmi method focused on 5 indicators, including counting error, visualization equation, algorithm, conclusion and accuracy in the process.

\section{A. Operation Error}

The results of student factoring by $\mathrm{Al}$ Khawarizmi showed that there were 10 students out of 32 students whose errors were in the operation. These mathematical operation errors may vary, it can be in the form of addition, subtraction, multiplication and division. The students' error in completing factorization can be seen in figure 4 . 


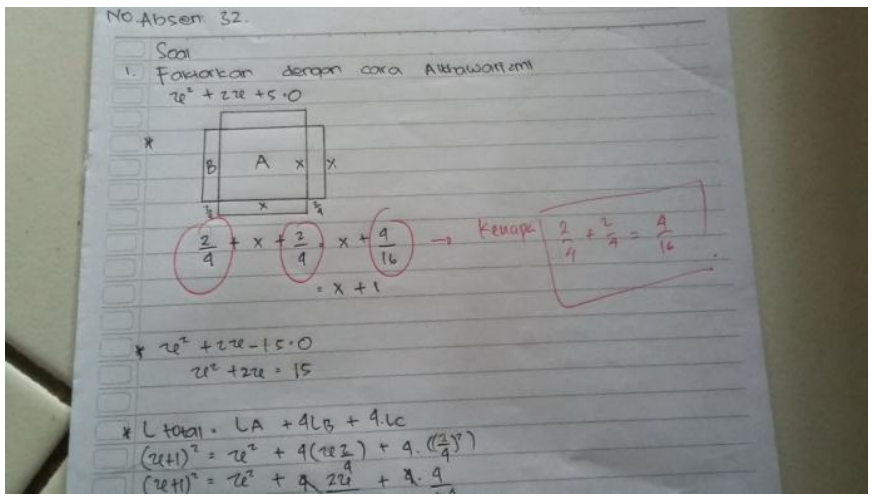

Fig. 4. Students' error in mathematical operation.

It can be seen in Figure 4 that students have problems in the mathematical operation $\frac{2}{4}+x+\frac{2}{4}=x+\frac{4}{16}$ the answer is supposed to be $\frac{2}{4}+x+\frac{2}{4}=x+\frac{4}{4}$ in not knowing about the sum arithmetic operation on the fraction. It is relevant to the previous research by [7] which in his research produced that one type of student error and the factor causing the student's mistake in working on the matter of algebraic factorization formation is a procedural error that includes errors in the addition operation, subtraction, multiplication and algebraic alteration, errors do not continue the settlement process, algebraic form, and error writing out the final result.

\section{B. Equation Visualization}

The second indicator seen by the researcher is the visualization of the equation. The visualization of the equation is changing from a quadratic equation to a geometric form. In this indicator, the researcher wants to see how students can change from a matter of quadratic equations to a square-shaped geometry. There are 14 students out of 32 students who are still lacking in visualizing the squared equations to square shapes. Visualization of this equation requires good student understanding. In a study conducted by Fachrudin [8] which revealed that students 'understanding of the concept of solving quadratic equations can be established by giving geometric problems as contextual problems at the beginning so that students' understanding can develop in geometry problems to the algebraic form of quadratic equations and their solutions. Student error in visualization of equation can be seen in Figure 5 .

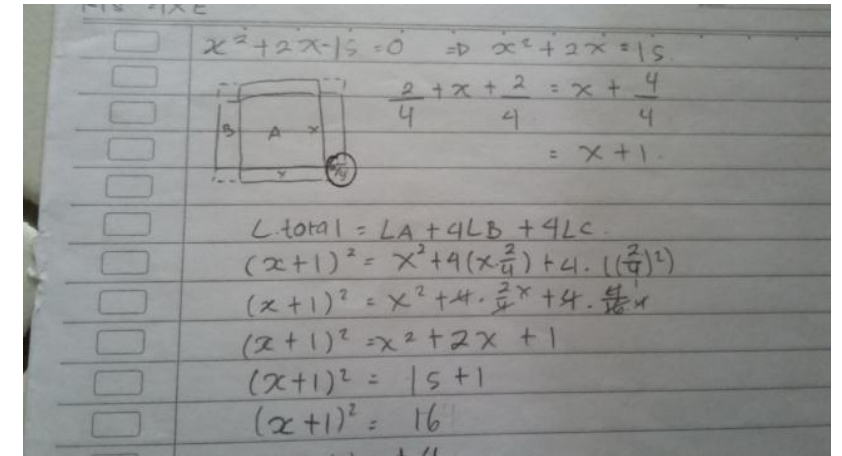

Fig. 5. Student error in visualization of equations.

The student's mistake in visualizing the equations is shown in Figure 5. In the student's work, the student is still confused in changing the equation $x^{2}+2 x-15=0$ in the form of a rectangle. On square it is correct that the students make a square with the size of the sides is $\mathrm{x}$. But on the smallest square, the students write down the length of the sides of the square is $\bar{y}$ the correct side length is $\frac{2}{4}$. In this case, students have not yet understood how to find the smallest square length lies on a large square corner.

\section{Algorithm}

Algorithm is a logical and systematic arrangement in solving a problem. In this study, the researcher wanted to know the student's way of thinking and the steps of the students in doing the factoring by $\mathrm{Al}$ Khawarizmi method. Of the 32 students studied, there were 3 students who did not systematize the steps. Students' Algorithm error can be seen in Figure 6.

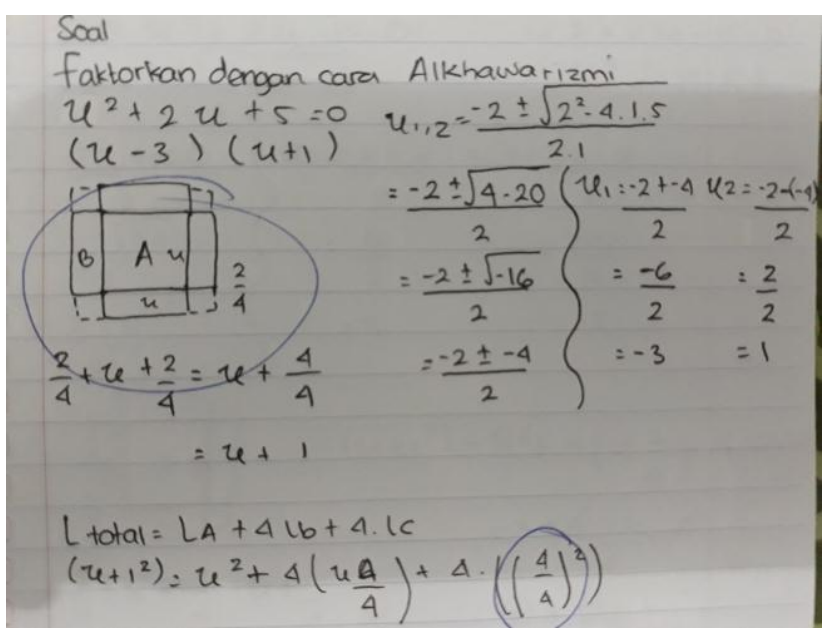

Fig. 6. Students' algorithm error.

Figure 6 shows that at first the students did not do the questions given using Al-Khawarizmi method, the students did try and error, then also tried to finish using the $\mathrm{ABC}$ formula. In the Al-Khawarizmi method the student should first determine the length of the large square side, then calculate the area of the large square and look for the factor of the equation 
applied to the problem. Students' errors in logical thinking that students can not understand a statement as a statement that generally and denied with enough examples [9].

\section{Drawing Conclusion}

Errors made by students and considered trivial is a mistake in writing out the final answer of the problem given. Based on the results of this study it is known that there are 19 students out of 32 students. This error is included in the category of errors that most often arise, this is because students feel they can do the work in accordance with the steps of the correct method. This type of error can be seen in figure 7 .

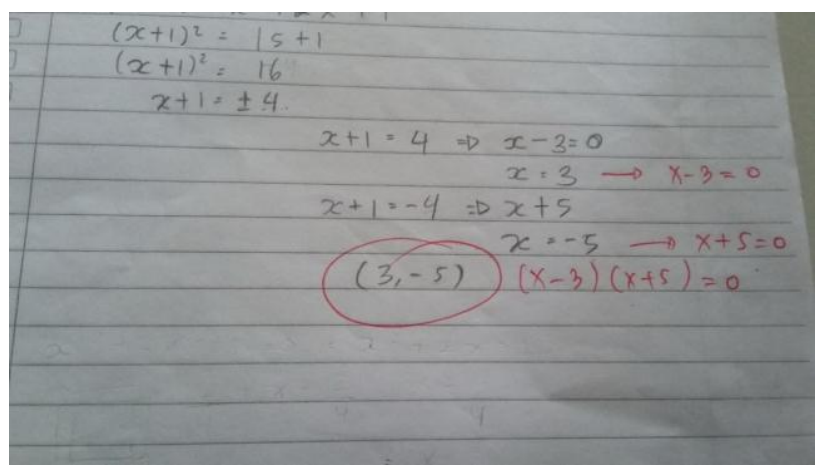

Fig. 7. The students error in drawing conclusion.

In Figure 7 it appears that there is a student error in writing the final result or concluding the answer. In the student's answer it appears that the students only arrive at $\mathrm{x}=3$ or $\mathrm{x}=$ 5 . The answer should be spelled out in factoring because of its factoring. So the factorial answer is $(x-3)(x+5)=0$. Students 'errors in writing mathematical symbols, the meaning of mathematical models, and inconsistencies in the meaning of mathematical symbols can arise because students' anxiety about the mathematical situation [10].

\section{E. Students' Accuracy}

Students' error in this study also includes students' accuracy in working on the question of factoring in the form of this algebra. Student accuracy is very important in the steps to do a problem, because although students understand how to do but the students are not careful in calculating the answer will be wrong. Therefore, researchers also want to know how thorough the students in calculating. Of the 32 students, it turns out there are 19 students who are less thorough in calculating. Student inaccuracy can be seen in Figure 8

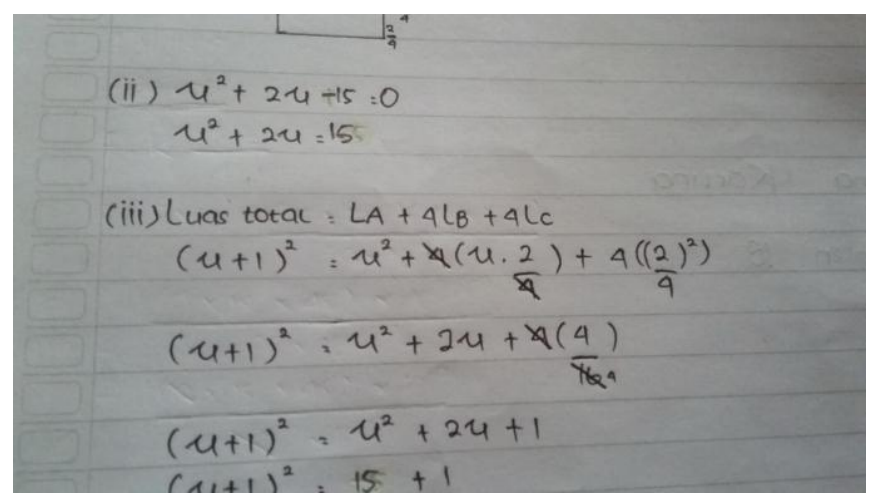

Fig. 8. Students' errors in accuracy.

Student inaccuracy in Figure 5 is seen in the location of

brackets in the squared system. The students wrote 4 . If it is written that way then squared only number 2 . The squared number is supposed to be $\frac{2}{4}$, the correct answer is $\left(\frac{2}{4}\right)^{2}$. The problem of accuracy in calculating this becomes one of the factors causing student error in working on the problem. The factor causing students' mistakes in working out the problems of algebraic factorization is that students do not understand how to operate algebraic form, students do not understand the problem well and the students are less careful in doing the questions [11].

Overall, the student's mistake in working out the factoring using Al Khawarizmi way can be presented in Table 1. 
TABLE I. STUDENTS ERROR SUMMARY

\begin{tabular}{|c|c|c|c|c|c|c|}
\hline \multirow[b]{2}{*}{ No } & \multirow[b]{2}{*}{ Name } & \multicolumn{5}{|c|}{ Indicators } \\
\hline & & Operations & $\begin{array}{c}\text { Equation } \\
\text { Visualization }\end{array}$ & Algorithm & Conclusion & Accuracy \\
\hline 1 & LA & & & & & 1 \\
\hline 2 & RS & & 1 & & & 1 \\
\hline 3 & ZMD & & 1 & & 1 & \\
\hline 4 & NSW & & 1 & & 1 & \\
\hline 5 & JKD & & & & 1 & \\
\hline 6 & DVD & & 1 & & 1 & 1 \\
\hline 7 & $\mathrm{NN}$ & & 1 & & & 1 \\
\hline 8 & BR & & & & & 1 \\
\hline 9 & DMS & & 1 & & 1 & 1 \\
\hline 10 & MY & & & & & 1 \\
\hline 11 & FAP & & 1 & & 1 & 1 \\
\hline 12 & $\mathrm{~K}$ & & 1 & & 1 & \\
\hline 13 & $\mathrm{TN}$ & 1 & & & 1 & 1 \\
\hline 14 & SHNA & & & & & \\
\hline 15 & HMZ & 1 & 1 & & 1 & 1 \\
\hline 16 & FAP & & & & & \\
\hline 17 & MP & 1 & 1 & 1 & & 1 \\
\hline 18 & SIR & & & & 1 & \\
\hline 19 & SPC & & & & 1 & 1 \\
\hline 20 & DFR & & & & & 1 \\
\hline 21 & NFA & & & & & \\
\hline 22 & AN & & & & 1 & 1 \\
\hline 23 & $\mathrm{~N}$ & 1 & & & & 1 \\
\hline 24 & FA & 1 & 1 & & 1 & 1 \\
\hline 25 & SS & 1 & 1 & & 1 & 1 \\
\hline 26 & $\mathrm{AZ}$ & 1 & 1 & & 1 & \\
\hline 27 & $\mathrm{AC}$ & 1 & & & & 1 \\
\hline 28 & RS & & & & 1 & \\
\hline 29 & AMMU & 1 & & & 1 & \\
\hline 30 & FN & & & & & \\
\hline 31 & DH & & 1 & 1 & 1 & \\
\hline 32 & GFS & 1 & & 1 & 1 & 1 \\
\hline Tota & & 10 & 14 & 3 & 19 & 19 \\
\hline
\end{tabular}

The following is described in detail the number and percentage of student errors that students made in Table 2. From Table 2, it can be seen that the greatest mistakes made by students on mistakes conclude answers or write down the final results of answers and about the accuracy of students in calculating.

TABLE II. PERCENTAGE OF STUdENT ERRORS FOR EACH INDICATOR

\begin{tabular}{|l|l|l|}
\hline \multicolumn{1}{|c|}{ Error Categories } & \multicolumn{1}{c|}{ Total } & \multicolumn{1}{c|}{ Percentage } \\
\hline Operations & 10 & $15,38 \%$ \\
\hline Equation Visualization & 14 & $21,54 \%$ \\
\hline Algorithm & 3 & $4,62 \%$ \\
\hline Conclusion & 19 & $29,23 \%$ \\
\hline Students' Accuracy & 19 & $29,23 \%$ \\
\hline
\end{tabular}

The percentage of student error for each indicator can also be seen in the diagram shown in Figure 9.

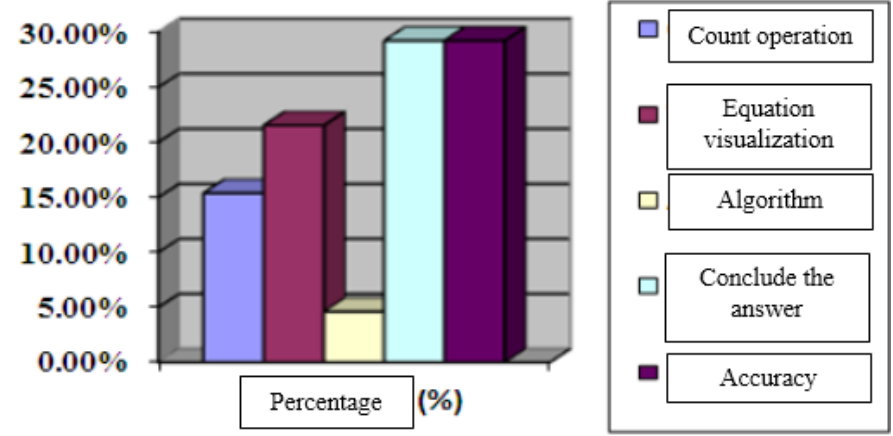

Fig. 9. Percentage of student errors for each indicator.

\section{CONCLUSION}

Based on the results of the research, it can be concluded that algebraic visualization with geometry by Al-Khawarizmi method helps students see algebra as something more real than just symbols of variables, coefficients and constants. It can be seen that the error in the algorithm is fewer than the others, meaning that the solution using the Al-Khawarizmi method is easily understood by the students. Demonstration of algebra in the form of geometry can be said not to be a significant 
constraint for students this is evidenced by only 14 students persuasion into the form of square and rectangular area. These results show that efforts to concrete algebraic forms should be improved in learning so that students can easily understand algebraic material, the Al-Khawarizmi method is particularly recommended to be taught to junior high school students in algebraic factorization materials so that students view algebra instead of an unbreakable abstract, that the introduction of this method will be an alternative and innovation in learning that adds students' insight into math.

\section{REFERENCES}

[1] L.A. Sari, "Diagnosis Kesalahan Siswa Sekolah Menengah Pertama dalam Menyelesaikan Masalah Faktorisasi Bentuk Aljabar," Universitas Pendidikan Indonesia. November, pp. 978-979, 2013.

[2] J.L. Booth and K.R. Koedinger, "Key misconceptions in algebraic problem solving," Proc. 30th Annu. Conf. Cogn. Sci. Soc., pp. 571-576, 2008.

[3] W.H. Carnahan, "History of Algebra Ii," Sch. Sci. Math., vol. 46, no. 2, pp. 125-130, 1946.

[4] D.M. Burton, The History of Mathematics: An Introduction, vol. 36, no. 11. 2010. from 32 students who make mistakes in drawing quadrat

[5] I.A. Ajwa, Z. Liu, P. S. Wang, and C. Science, "Gröbner Bases Algorithm," Computer (Long. Beach. Calif)., pp. 1-14, 2003.

[6] A.S. Ali, S. Pavlov, and K. Yordzhev, "The mathematics in middle-aged Arab caliphate and it application to contemporary teaching in high schools," no. 1, 2016.

[7] S. Intan, "Analisis Kesalahan Siswa Kelas Viii Dalam Menyelesaikan Soal Pada Materi Faktorisasi Bentuk Aljabar Smp Negeri 1 Kamal Semester Gasal Tahun Ajaran 2013/2014," MATHEdunesa J. Ilm. Pendidik. Mat., vol. 3, no. 2, 2014.

[8] A.D. Fachrudin, "Pendekatan Geometri untuk Membangun Konsep Penyelesaian Persamaan Kuadrat Berdasarkan Perspektif Sejarah,” J. Edukasi, vol. 1, no. 2, pp. 215-228, 2015.

[9] Subanji and T. Nusantara, "Karakterisasi Kesalahan Berpikir Siswa Dalam Mengonstruksi Konsep Matematika," J. Ilmu Pendidik., vol. 19, no. 2, pp. 208-217, 2013.

[10] M. Irfan, "Analisis Kesalahan Siswa dalam Pemecahan Masalah Berdasarkan Kecemasan Belajar Matematika," vol. 8, no. 2, pp. 143$149,2017$.

[11] A. Wahbi and A. Bey, "Analysis of Errors of Students in Solving Algebraic Factorization," J. Penelit. Pendidik. Mat., vol. 3, no. 1, pp. 19-30, 2015. 